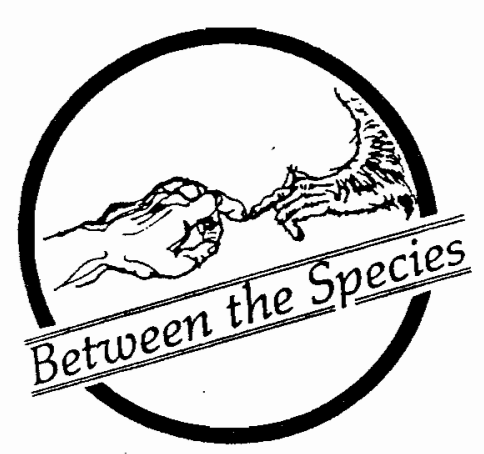

\title{
Reply to Miller
}

Harlan Miller has correctly identified the key concept of my proposed umbrella moral theory for animal liberation and environmental ethics - the "community concept," as Aldo Leopold called it in "The Land Ethic" of A Sand County Almanac. And Miller is right to point out that "community," as it appears in my argument, it not a univocal term. As I move from family and tribe and Midgley's mixed community to the global village and the biotic community, I shift from the conventional or lexical meaning of "community" to some other nonstandard sense. But the word "community," at least as it appears in the paper of mine here under discussion, is not, therefore, simply ambiguous - its various senses united only by etymology - nor may my argument be summarily dismissed as a case of the fallacy of amphiboly. As I have elsewhere pointed out, the ecological concept of a biotic community is analogical. In ecology, the organization of living nature has been fruitfully compared to paradigmatic communities - communities in the literal sense of the term. In Charles Elton's classical formulation, the analogical character of the concept of a "biotic community" is very evident. Elton sometimes spoke, for example, of plants and animals occupying "professions" in the "economy of nature." The critical question, then, is this: Are biotic communities similar to paradigmatic communities in morally relevant ways? I think that they are and, curiously, so does Miller - despite what he says toward the beginning of his commentary on my paper.

\section{J. Baird Callicott}

Miller begins by identifying "affectional communities," which are just those paradigmatic communities to which I referred, communities in the lexical sense, communities par excellence. Then he tells us that the biotic community is too large and varied to be an affectional community. Therefore, since, following Hume, I ground morality in feeling or affection, upon my preferred moral theory the biotic community is beyond the moral pale.

Had Miller left it at that, I would have had to say here that human moral sentiments, though a legacy of our evolutionary heritage, are underdetermined. Although they evolved through "kin selection" and originally extended only to family and clan conspecifics, they are plastic and may be molded by cultural information. They may be, and in fact have been, stretched to encompass first the people over the hill and across the river, then those beyond the mountains and the seas, and, by now, among enlightened folk, they encompass all 5 billion Homo sapiens. We are all, as our most enlightened moralists tell us, "brothers and sisters under the skin." What counts as a small, cozy kinship group depends on your frame of reference. For cave-persons it was a band of 50 or so people and half as many dogs. Later

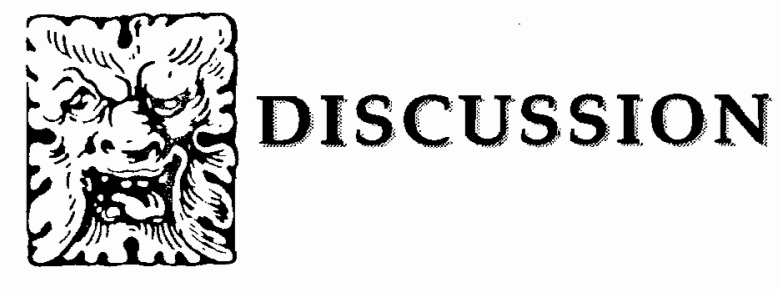


it was the city-state; later still, the nation-state. Since the Copernican and Darwinian revolutions our spatial and temporal horizons have been considerably expanded and with them our perception of the limits of our affectional (moral) "community." The Earth is a "small planet" in a vast galaxy in a still vaster universe. All its contemporary denizens are coevolved and possibly descended from a single cell. The biotic community, from this point of view, looks like a congeries of tribes, descended from a common ancestor, living symbiotically on an island paradise in the midst of a hostile and desert ocean. In an astronomical and geological frame of reference the biotic community seems familial and its members our sisters, brothers, cousins, uncles, aunts, grandfathers, and grandmothers - as American Indians sometimes, in fact, characterize them.

But Miller, in effect, says all of this for me. He writes: "That altruism emerged within limited groups [affectional communities] is almost certainly true. But that is no reason to argue that altruism should remain confined to such groups." I never argued it, although Garrett Hardin has in his paper, "Discriminating Altruism." Miller goes on: "Thus universal principles [ethics, as he explains] have their origins in sympathy and affectional community, but far outrun those origins as we (both individual and societies) grow. Our hearts can not encompass the world, but our heads can see that what the heart cares for extends beyond the limits of the heart's vision." My point exactly! I just wish that I could so facilely turn out such poetic phrases. Hence, so far as my central argument is concerned, I find myself not replying to Miller but quoting him to support my contention. (As to the implications of this forensic irony for the self-consistency of Miller's commentary, I leave the reader to judge for him- or herself.)

Miller and I do have one central point of disagreement. In his view, the ethical principles generated by our moral sentiments should remain the same in each stratum of our community involvements. I think the different relationships within our various communities generate different proximate moral principles in each case - family, and extended family, national, mixed, international, and biotic communities.

Finally, I would like to dispute an allegation which Miller directs to me personally. He says that I "just accept the undefended assertion that the beauty, integrity, and stability of the biotic community are morally prior to the interests of the members of the community." I don't "just" accept the assertion that follows "that" in Miller's sentence. In fact, without further qualification I don't accept it at all. I have been at pains to point out in a variety of venues (including the paper under discussion), that the land ethic is only one ethical accretion among many, each correlative to our nested community involvements, and, further, that the obligations correlative to the inner, more intimate communities preempt those correlative to the outer, less intimate ones. Other things being equal, obligations to family members come before obligations to anonymous human beings, and obligations to human beings, individually, come before our duties to the environment. So, when we are talking about the interests of the human members of the biotic community, I certainly do not accept the assertion that they are subordinate to its integrity, stability, and beauty.

Let me hasten to say, having emphatically registered this qualification, that in purely environmental cases our obligations are primarily to the community as a whole, and where conflicts arise, the integrity, stability, and beauty of the biotic community preempt environmental ethical duties that we may owe to individual biotic community members (when those members are not family members, fellow human beings, or members of the mixed community). The land ethic, sui generis, is, in other words, holistic.

I accept this assertion, but I don't just accept it, nor is it "undefended." I derive it from the structure of the biotic community. It is therefore defended. But I cannot fully defend it here because, of course, that would involve opening a whole 'nother can of worms. (Actually several cans, beginning with the is/ought dichotomy and naturalistic fallacy and ending with the metaphysical implications of ecology.) "Animal Liberation and Environmental Ethics: Back Together Again" will appear in a book of my collected essays called In Defense of the Land Ethic: Essays in Environmental Philosophy which will be published by the State University of New York Press in 1989. I cannot altogether fault Harlan Miller for thinking that the moral priority of the integrity, stability, and beauty of the biotic community has gone undefended, because I have so far only managed to defend it in scattered essays which Miller may not have run across in his reading. When these essays are published as a collection then Miller and other critics of the land ethic will have less of an excuse for this particular permutation of the argumentum ad ignorantum. 